\title{
Morphological and biochemical changes in response to salinity in sunflower (Helianthus annus L.) cultivars
}

\author{
Mehdi Taher, ${ }^{1}$ Ramazan Beyaz, ${ }^{2}$ Marieh Javani, ${ }^{1}$ Mehtap Gürsoy, ${ }^{3}$ Mustafa Yildiz ${ }^{1}$ \\ ${ }^{1}$ Department of Field Crops, Graduate School of Natural and Applied Sciences, Ankara University, Dışkapt, \\ Ankara; ${ }^{2}$ Department of Soil Science and Plant Nutrition, Faculty of Agriculture, Ahi Evran University, \\ Bağbaşı, Kırşehir; ${ }^{3}$ Güzelyurt Vocational School, Aksaray University, Güzelyurt, Aksaray, Turkey
}

\begin{abstract}
This study was conducted to evaluate the alterations of some morphological and biochemical parameters of sunflower cultivars ('08-TR-003', 'TR-3080' and 'TARSAN-1018') under salt stress. For this aim, the seedling of sunflower cultivars was irrigated with tap water as a control, and with salinised water with 50, 150 and $250 \mathrm{mM} \mathrm{NaCl}$ for 30 days under controlled conditions. Salinity caused an apparent reduction in morphological parameters (plant height, leaf area, fresh weight, dry matter and water content) in all cultivars. Salt stress significantly $(\mathrm{P}<0.01)$ reduced the activity of glutathione reductase (GR) and ascorbate peroxidase (APX) activities in all sunflower cultivars expect for superoxide dismutase (SOD) activity. According to our results, SOD seems to play a key role in the antioxidative process in salt treated sunflower plants. Proline and malondialdehyde contents were significantly $(\mathrm{P}<0.05)$ increased under salt stress in all cultivars. Among the cultivars, 'TR-3080' had greater values in terms of morphological (plant height, leaf area, fresh weight, water content) and biochemical [GR, APX and SOD (secondly) activities and proline contents] parameters. In the light of these findings, cv. 'TR-3080' seems to be less affected by salt stress.
\end{abstract}

Correspondence: Ramazan Beyaz, Department of Soil Science and Plant Nutrition, Faculty of Agriculture, Ahi Evran University, Bağbaşı, Kırşehir, Turkey.

E-mail: ramazanbeyaz@gmail.com

Key words: Sunflower; $\mathrm{NaCl}$; antioxidant enzymes; proline; malondialdehyde.

Received for publication: 17 August 2017.

Revision received: 8 November 2017.

Accepted for publication: 10 November 2017.

CCopyright M. Taher et al., 2018

Licensee PAGEPress, Italy

Italian Journal of Agronomy 2018; 13:1096

doi:10.4081/ija.2018.1096

This article is distributed under the terms of the Creative Commons Attribution Noncommercial License (by-nc 4.0) which permits any noncommercial use, distribution, and reproduction in any medium, provided the original author(s) and source are credited.

\section{Introduction}

Biotic and abiotic stresses are the main problems of agricultural systems. Salinity is also considered as a major abiotic stress and a significant factor affecting crop production all over the world (about $7 \%$ of arable lands of the world are under salinity pressure) and especially in arid and semi-arid regions (Bajehbaj, 2010). Throughout semi-arid regions of temperate climates, the most important oil-yielding crop is sunflower (Helianthus annuus L.) (Jabeen and Ahmad, 2012). Sunflower (Helianthus annuus L.), a species of the Asteraceae family, is an important annual economic (edible or oil-producing) oilseed crop that is ranked as the $4^{\text {th }}$ important vegetable oil crop after soybean, palm oil and rapeseed (Wen-Zhi et al., 2014; Achakzai et al., 2015; Bakhoum and Sadak, 2016). It is grown around the world and is a popular crop in countries that have salt affected soils (Masor, 2011). The soil salinity level was the main limiting factor for vegetative growth of sunflower (Ma et al., 2016). Sunflower (Helianthus annuus L.) has been rated as moderately salt-resistant with no significant yield reduction up to $4.8 \mathrm{dS} \mathrm{m}^{-1}$, and variability for salt resistance has been detected within this crop (Ceccoli et al., 2012; Machekposhti et al., 2017).

Salinity adversely affects important physiological processes and biochemical mechanisms, causes severe loss in crop productivity worldwide (Per et al., 2017) and can cause some biochemical changes in plant cell such as losing of cell turgor and the accumulation of reactive oxygen species (ROS) (Nxele et al., 2017). ROS including hydrogen peroxide $\left(\mathrm{H}_{2} \mathrm{O}_{2}\right)$, superoxide anions $\left(\mathrm{O}_{2}\right.$ --), hydroxyl radical $(\mathrm{OH} \bullet)$ and singlet oxygen $\left({ }^{1} \mathrm{O}_{2}\right)$ are by-products of physiological metabolisms, and are precisely controlled by enzymatic and non-enzymatic antioxidant defense systems (You and Chan, 2015). The main antioxidant enzymes include superoxide dismutase (SOD), catalase, ascorbate peroxidase (APX), glutathione reductase (GR) and the activities of these enzymes are generally increased in plants under oxidative stress conditions (Bela et al., 2015; Vighi et al., 2017). One of the other cellular responses to saline conditions is the alteration of metabolism and production of compatible solutes (osmolytes) such as proline, which are distributed among different organisms (Mansour and Ali, 2017). The accumulation of proline (Pro) is one of the striking metabolic responses of plants to salt stress (Per et al., 2017). One of the cell parts where stress-related oxidative damage has the most effect is the cell membrane. As a result of oxidative damage, lipid peroxidation occurs in cell membranes and the permeability of the membrane is damaged. Lipid peroxidation can be measured with the help of malondialdehyde (MDA), which is a byproduct of this process (Koç, 2015). There are limited reports (RiosGonzalez et al., 2002) on the morphological and biochemical responses of sunflower to soil salinity. Therefore, this study was 
conducted to evaluate the alterations of some morphological and biochemical parameters of different sunflower cultivars under salt stress.

\section{Materials and methods}

\section{Plant material}

Oil type sunflower cultivars '08-TR-003', 'TR-3080' and 'TARSAN-1018' obtained from Trakya Agricultural Research Institute were used in the study.

\section{$\mathrm{NaCl}$ experiments, planting and plant development}

For each $\mathrm{NaCl}$ concentration and genotype, four replicates were tested, and there was one plant per replication. $500 \mathrm{~mL}$ pots were used in all experiments and one seed was sown in each pot. After sowing, each pot was irrigated with $50 \mathrm{~mL}$ tap water. After one week from sowing, pots were irrigated with $50 \mathrm{~mL}$ tap water containing different $\mathrm{NaCl}$ concentrations (0-control, 50, 150 and $250 \mathrm{mM}$ ) for four weeks. Tap water without $\mathrm{NaCl}$ was used as a control. All experiments were conducted in the controlled growth chamber for incubation at $24^{\circ} \pm 1^{\circ} \mathrm{C}$ under cool white fluorescent light $\left(27 \mathrm{mmol} \mathrm{m}^{-2} \mathrm{~s}^{-1}\right)$ with a $16 \mathrm{~h}$ light $/ 8 \mathrm{~h}$ dark photoperiod.

\section{Morphological characters}

After sowing, seeds were irrigated with $50 \mathrm{~mL}$ tap water for 10 days. First $\mathrm{NaCl}$ treatments began after these 10 days. Plantlets were watered with tap water $(50 \mathrm{~mL})$ containing different $\mathrm{NaCl}$ concentrations (0-control, 50, 150 and $250 \mathrm{mM}$ ) every two days. The application continued for 30 days, and then measurements were made. Fresh weight ( $\mathrm{g}$ ) of leaves was measured with a precision scale. Dry weights were measured after drying samples at $70^{\circ} \mathrm{C}$ for $48 \mathrm{~h}$ in an oven. Water content was calculated with the following formula:

Water content $(g)=$ Fresh weight of leaf $(g)-$ Dry weight of leaf $(g)$

Percentages of dry matter and water content were measured with the following formulas:

Dry matter $(\%)=\frac{\text { Dry weight of leaf }(g)}{\text { Fresh weight of leaf }(g)} \times 100$

Water content $(\%)=\frac{\text { Dry weight of leaf }(g)-\text { Fresh weight of leaf }(g)}{\text { Fresh weight of leaf }(g)} \times 100$

\section{Biochemical observation}

\section{Measurement of antioxidant enzymes}

To determine the enzyme changes in plants under salt stress, approximately $1 \mathrm{~g}$ of fresh leaf samples in liquid nitrogen were ground up in porcelain mortars and homogenised with $10 \mathrm{~mL}$ of a $50-\mathrm{mM}$ phosphate buffer solution containing $0.1 \mathrm{mM}$ of Na-EDTA ( $\mathrm{pH}$ 7.6). Homogenised samples were centrifuged at 15,000 rpm for $15 \mathrm{~min}$ and the resultant precipitates were used in enzyme analyses. Samples were kept at $+4^{\circ} \mathrm{C}$ until the enzyme analyses were performed. For the enzyme measurements, final volumes were obtained using the buffer solution.

\section{Superoxide dismutase activity}

Superoxide dismutase activity was determined by using the method proposed by Cakmak and Marschner (1992), and Cakmak (1994), based on the reduction of nitro blue tetrazolium chloride (NBT) by $\mathrm{O}_{2}$ - under light. All the solutions were added into the reaction medium: first, $0.1 \mathrm{mM}$ of Na-EDTA containing $50 \mathrm{mM}$ (pH: 7.6) phosphate (P) buffer, then, the enzyme extract (25 to 100 $\mu \mathrm{L}$ ) followed by $0.5 \mathrm{~mL}$ of $50 \mathrm{mM} \mathrm{Na}_{2} \mathrm{CO}_{3}$ (pH of 10.2), $0.5 \mathrm{~mL}$ of $12 \mathrm{mM}$ of L-methionine, $0.5 \mathrm{~mL}$ of $75 \mu \mathrm{m}$ of $\mathrm{p}$-NBT and $10 \mu \mathrm{m}$ of riboflavin were each added into the medium so that the final volume of the medium was $5 \mathrm{~mL}$. The samples were kept under light for $15 \mathrm{~min}$ and measurements were carried out at $560 \mathrm{~nm}$.

\section{Ascorbate peroxidase activity}

Ascorbate peroxidase activity was measured by using the method proposed by Cakmak and Marschner (1992), and Cakmak (1994), based on the oxidation of ascorbate at $290 \mathrm{~nm}(\mathrm{E}=2.8 \mathrm{mM}$ $\mathrm{cm}^{-1}$ ). By following the method, the final volume of the reaction medium was adjusted to $1 \mathrm{~mL}$ by adding $0.1 \mathrm{mM}$ of EDTA containing a $50-\mathrm{mM}$ phosphate buffer ( $\mathrm{pH}$ of 7.6), $0.1 \mathrm{~mL}$ of $10 \mathrm{mM}$ of EDTA containing $12 \mathrm{mM}$ of $\mathrm{H}_{2} \mathrm{O}_{2}, 0.1 \mathrm{~mL}$ of $0.25 \mathrm{mM}$ of Lascorbic acid and enzyme extract into the medium, and then the ascorbate concentration was measured at $290 \mathrm{~nm}$ using spectrophotometry.

\section{Glutathione reductase activity}

Glutathione reductase activity was measured with the method proposed by Cakmak and Marschner (1992), and Cakmak (1994), based on the oxidation of NADPH at $340 \mathrm{~nm}\left(E=6.2 \mathrm{mMcm}^{-1}\right)$. By following the method, the final volume of the reaction medium was adjusted to $1 \mathrm{~mL}$ by adding $0.1 \mathrm{mM}$ of EDTA containing a 50$\mathrm{mM}$ phosphor buffer ( $\mathrm{pH}$ of 7.6$), 0.1 \mathrm{~mL}$ of $0.5 \mathrm{mM}$ of oxidised glutathione, $0.1 \mathrm{~mL}$ of $0.12 \mathrm{mM}$ of NADPH and enzyme extract into the medium, and then the NADPH oxidation was measured at $340 \mathrm{~nm}$.

\section{Measurement proline and lipid oxidation (malondialdehyde content)}

The proline assay was based on the method of Bates et al. (1973), which uses 3\% sulfosalicylic acid for grinding the fresh plant samples. The ninhydrin reagent was added to the tubes containing the ground sample, which were then placed in a water bath at $100^{\circ} \mathrm{C}$ for $1 \mathrm{~h}$. After cooling, $4 \mathrm{~mL}$ of toluene were added to the samples. The samples were measured at $520 \mathrm{~nm}$. MDA was determined according to Lutts et al. (1996). Briefly, $5 \mathrm{~mL}$ trichloroacetic acid $(0.1 \%)$ were added to the sample of $200 \mathrm{mg}$ fresh leaves, and then centrifuged at 12,500 rpm for $20 \mathrm{~min} ; 3 \mathrm{~mL}$ supernatant were taken from $5 \mathrm{~mL}$ extracts. Three milliliters of $0.1 \%$ thiobarbituric acid in $20 \%$ trichloroacetic acid $(\mathrm{w} / \mathrm{v})$ were added to an equal amount of each of the supernatants. The Aabsorbance of the samples was measured using a spectrophotometer at 532 and $600 \mathrm{~nm}$.

\section{Statistical analysis}

The experimental design was completely randomised design with four replications. Each treatment was arranged in $500 \mathrm{~mL}$ pots containing 5 plants. For all investigated parameters, Analysis of Variance was performed by using the SPSS for Windows computer software. Means of treatments were compared with Duncan's multiple range test by using 'MSTAT-C' computer software. Data given in percentages were subjected to arcsine $(\sqrt{ } X)$ transformation before statistical analysis (Snedecor and Cochran, 1967). 


\section{Results and discussion}

The obtained results presented in Tables 1-4 show that, salt stress significantly reduced all growth characters (plant height, leaf area, fresh weight, dry matter and water contents) of the three sunflower cultivars ('08-TR-003', 'TR-3080' and 'TARSAN-1018'). Results of two-way ANOVA in the characters of plant height and leaf surface area showed that there were statistically significant $(\mathrm{P}<0.01)$ interactions between cultivars and salt concentrations while interaction between cultivars and salt concentrations in fresh weight was significant at 0.05 level (Table 1). From the mean data, it is apparent that cv. 'TR-3080' had greater plant height (21.33 $\mathrm{cm})$ and fresh weight $(7.47 \mathrm{~g})$ than the other cultivars at the highest $\mathrm{NaCl}$ concentration $(250 \mathrm{mM})$ (Table 2). Leaf area is a good indicator of water and salinity stress (Kumar et al., 2014). In the present study, salt stress significantly $(\mathrm{P}<0.01)$ reduced leaf area of the three sunflower cultivars ('08-TR-003', 'TR-3080' and 'TARSAN-1018') (Figure 1). The highest value (45.46 mm², 43\% decrease when compared to control) was registered in cv. 'TR3080 ' at the highest $\mathrm{NaCl}$ concentration $(250 \mathrm{mM}) .34 .42 \mathrm{~mm}^{2}$ and $26.32 \mathrm{~mm}^{2}$ were recorded in cv. '08-TR-003' and 'TARSAN-1018' with $49 \%$ and $65 \%$ decreasing rate, respectively (Table 2). Adverse effects of salt stress on leaf area of sunflower have also been reported by several authors (Rivelli et al., 2010; Achakzai et al., 2015; Khan et al., 2016). Data related to fresh weight showed that the results dramatically decreased by increasing salt concentrations in all cultivars. The highest results regarding fresh weight were recorded at all salt concentrations from cv. 'TR-3080' (Table 2). Lower fresh weight at higher salt concentrations was due to decreasing water absorption (Prado et al., 1995). It was reported that fresh weight increase was based on cell enlargement due to water intake, cell vacuolation and turgor-driven wall expansion (Dale, 1988).

There were statistically significant interactions between cultivars and salt concentrations on dry matter content, dry matter per- centage and water content percentage at 0.01 level (Table 3 ). Since no interaction was determined between cultivars and salt concentrations in water content, the effects of these factors was analysed separately (Table 3). Both factors (cultivars and salt concentrations) affected water content significantly at 0.01 level. In term of dry matter, the highest value was registered in cv. 'TARSAN-1018' with $1.25 \mathrm{~g}$ (13\% decrease compare to control) at $250 \mathrm{mM} \mathrm{NaCl}$. The dry matter of cv. 'TR-3080' and '08-TR-003' was $1.03 \mathrm{~g}(50 \%$
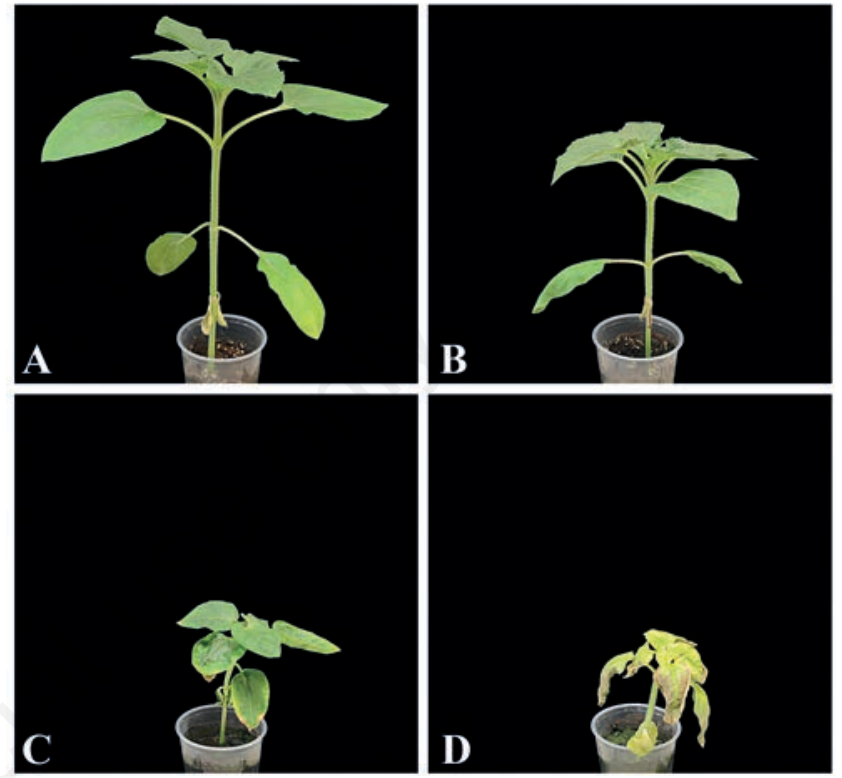

Figure 1. The effect of different salt concentrations on seedling growth of sunflower cv. 'TARSAN 1018'. A) $0 \mathrm{mM}$ (control); B) $50 \mathrm{mM}$; C) $150 \mathrm{mM}$; and D) $250 \mathrm{mM}$.

Table 1. Results of two-way ANOVA of the effect of different cultivars and salt concentrations on plant height, leaf surface area and fresh weight.

\begin{tabular}{|c|c|c|c|c|c|c|c|c|c|c|c|c|c|}
\hline \multirow[t]{2}{*}{ Source } & \multirow[b]{2}{*}{ df } & \multicolumn{4}{|c|}{ Plant height (cm) } & \multicolumn{4}{|c|}{ Leaf surface area $\left(\mathrm{mm}^{2}\right)$} & \multicolumn{4}{|c|}{ Fresh weight (g) } \\
\hline & & $\begin{array}{c}\text { Sum } \\
\text { of squares }\end{array}$ & $\begin{array}{l}\text { Mean } \\
\text { square }\end{array}$ & $F$ & Sig. & $\begin{array}{l}\text { Sum } \\
\text { of squares }\end{array}$ & $\begin{array}{l}\text { Mean } \\
\text { square }\end{array}$ & F & Sig. & $\begin{array}{l}\text { Sum } \\
\text { of squares }\end{array}$ & $\begin{array}{l}\text { Mean } \\
\text { square }\end{array}$ & $\mathbf{F}$ & Sig. \\
\hline Corrected model & 11 & 840.3 & 76.4 & 32.9 & 0.000 & 8981.5 & 816.5 & 101.1 & 0.000 & 370.8 & 33.7 & 54.4 & 0.000 \\
\hline Intercept & 1 & $17,689.0$ & $17,689.0$ & 7626.4 & 0.000 & $111,915.9$ & $111,915.9$ & $13,862.3$ & 0.000 & 3765.7 & 3765.7 & 6077.5 & 0.000 \\
\hline Cultivar & 2 & 296.2 & 148.1 & 63.8 & 0.000 & 1035.9 & 518.0 & 64.2 & 0.000 & 31.0 & 15.5 & 25.1 & 0.000 \\
\hline Salt & 3 & 484.9 & 161.6 & 69.7 & 0.000 & 7642.5 & 2547.5 & 315.5 & 0.000 & 330.1 & 110.0 & 177.6 & 0.000 \\
\hline Cultivar * Salt & 6 & 59.3 & 9.89 & 4.3 & 0.005 & 303.1 & 50.5 & 6.3 & 0.000 & 9.7 & 1.6 & 2.6 & 0.043 \\
\hline Error & 24 & 55.7 & 2.3 & & & 193.8 & 8.1 & & & 14.8 & 0.6 & & \\
\hline Total & 36 & $18,585.0$ & & & & $121,091.2$ & & & & 4151.4 & & & \\
\hline Corrected total & 35 & 896.000 & & & & 9175.3 & & & & 385.7 & & & \\
\hline
\end{tabular}

Table 2. The effect of different cultivars and salt concentrations on plant height, leaf surface area, fresh weight in sunflower.

\begin{tabular}{lccccccccccccc} 
Cultivars & NaCl & \multicolumn{4}{c}{ Plant height $(\mathrm{cm})$} & \multicolumn{4}{c}{ Leaf surface area $\left(\mathrm{mm}^{2}\right)$} & \multicolumn{4}{c}{ Fresh weight $(\mathrm{g})$} \\
& Cont. $(\mathrm{mM})$ & 0 & 50 & 150 & 250 & 0 & 50 & 150 & 250 & 0 & 50 & 150 & 250 \\
'TARSAN 1018' & $24.83^{\mathrm{bc}}$ & $21.50^{\mathrm{cd}}$ & $19.17^{\mathrm{de}}$ & $12.83^{\mathrm{f}}$ & $75.33^{\mathrm{ab}}$ & $62.67^{\mathrm{cd}}$ & $44.79^{\mathrm{e}}$ & $26.32^{\mathrm{g}}$ & $13.56^{\mathrm{b}}$ & $10.52^{\mathrm{c}}$ & $7.22^{\mathrm{d}}$ & $4.48^{\mathrm{e}}$ \\
'TR-3080' & $33.33^{\mathrm{a}}$ & $26.00^{\mathrm{b}}$ & $24.00^{\mathrm{bc}}$ & $21.33^{\mathrm{cd}}$ & $81.17^{\mathrm{a}}$ & $69.00^{\mathrm{bc}}$ & $57.71^{\mathrm{d}}$ & $45.46^{\mathrm{e}}$ & $15.89^{\mathrm{a}}$ & $11.26^{\mathrm{c}}$ & $9.82^{\mathrm{c}}$ & $7.47^{\mathrm{d}}$ \\
\hline '08-TR-003' & $23.33^{\mathrm{bc}}$ & $22.00^{\mathrm{cd}}$ & $21.00^{\mathrm{cd}}$ & $16.67^{\mathrm{e}}$ & $67.13^{\mathrm{c}}$ & $57.00^{\mathrm{d}}$ & $48.08^{\mathrm{e}}$ & $34.42^{\mathrm{f}}$ & $14.79^{\mathrm{ab}}$ & $10.44^{\mathrm{c}}$ & $9.97^{\mathrm{c}}$ & $7.31^{\mathrm{d}}$ \\
\hline
\end{tabular}

a-eValues in a row and in a column (for water content in g) followed by the different letters are significantly different at the 0.01 level. 
decrease) and $0.62 \mathrm{~g}$ (68\%decrease), respectively (Table 4). According to Nobre et al. (2010) salinity affects the plant dry matter production because the high salt concentrations at the root zone decrease water availability. Sunderland (1960) reported that dry weight content of the leaf depended on cell division and new material synthesis. However, it was reported that one of the reasons of dry matter decrease in sunflower cultivars was salt stress (Rivelli et al., 2010; Maia et al., 2016; Khan et al., 2016). The highest water content was observed in the cv. 'TR-3080' (6.44 g, 53\% decrease compare to control) at $250 \mathrm{mM} \mathrm{NaCl}$. The water content of cv. '08-TR-003' and 'TARSAN-1018' was $6.06 \mathrm{~g}(54 \%$ decrease) and $3.06 \mathrm{~g}(66 \%$ decrease $)$ at $250 \mathrm{mM} \mathrm{NaCl}$, respectively (Table 2). Jabeen and Ahmad (2012) stated that imposition of salt stress also had adverse effects on relative leaf water content in sunflower. Overall, decrease in growth is one of the most commonly observed symptoms in plants grown in saline environments and has been well documented some sunflower cultivars (Steduto et al., 2000; Rios-Gonzales et al. 2002; Hussain et al., 2012). Water content in $\mathrm{g}$ decreased significantly by increasing salt concentrations. The highest water was noted in control treatment, while the lowest values were obtained from $250 \mathrm{mM} \mathrm{NaCl}$ treatment. Lower levels of all parameters at higher $\mathrm{NaCl}$ concentrations could be attiributed to the decreasing amount of water absorption from the soil and consequently, to a reduced uptake of solutes due to lower osmotic pressure of the roots. The inhibition of growth under water stress conditions hinders cell division and elongation (Hsia, 1973). Osmotic stress hinders cell wall extension (Van Volkenburg and Boyer, 1985). Karmoker and Van Steveninck (1979) stated that stress-induced growth reduction could be due to changes in membrane permeability and water absorption.

Statistical analysis showed that there were statistically signifi- cant $(\mathrm{P}<0.01)$ interactions between cultivars and salt concentrations in proline and lipid peroxidation (MDA) contents, activity of ascorbate peroxidase and superoxide dismutase. In glutathione reductase activity, no interaction was observed between cultivars and salt concentrations. That was because the effect of these factors was analysed separately. The effects of cultivars and salt concentrations on glutathione reductase activity were found statistically significant at 0.01 level (Table 5). Our results show that increasing the $\mathrm{NaCl}$ concentration significantly reduced the activity of GR and APX activities in all sunflower cultivars except for SOD activity compared to control (Table 6). GR is a potential enzyme of the ASH-GSH cycle and plays an essential role in the defense system against ROS by sustaining the reduced status of GSH (Gill and Tuteja, 2010). The highest activity of GR was observed in 'TR3080' (102.78 $\mathrm{mmol} \mathrm{min}^{-1} \mathrm{mg}^{-1} \mathrm{FW}, 8.51 \%$ decrease compared to control) at highest $\mathrm{NaCl}$ concentration $(250 \mathrm{mM})$. However, GR activities were 96.00 and 94.00 unit $^{-1} \mathrm{~min}^{-1} \mathrm{mg} \mathrm{FW}$ in 'TARSAN1018' and '08-TR-003', respectively. The percentage decreases were $17.64 \%$ and $8.05 \%$ at $250 \mathrm{mM} \mathrm{NaCl}$ concentration in 'TARSAN1018' and '08-TR-003', respectively. The first enzyme of the ascorbate-glutathione cycle, APX, plays a vital role in the elimination of $\mathrm{H}_{2} \mathrm{O}_{2}$ (Vighi et al., 2017). At $250 \mathrm{mM} \mathrm{NaCl}$ level, the highest activity of APX (2730.96 $\left.\mathrm{mmol} \mathrm{min}^{-1} \mathrm{mg}^{-1} \mathrm{FW}\right)$ was recorded in cv. 'TR-3080' in control treatment. However, APX activities were 1759.73 and $1532.99 \mathrm{mmol} \mathrm{min}^{-1} \mathrm{mg}^{-1} \mathrm{FW}$ in '08TR-003' and 'TARSAN1018', respectively. Accelerated salt stress reduced APX activities by $35.57 \%$ and $12.39 \%$, in '08-TR-003 and 'TARSAN1018', respectively. In an oxidative defense system, SOD has an important role in the first dismutation ROS. Unlike the other enzymes, our results show that SOD activity increases with increasing $\mathrm{NaCl}$ concentrations in all cultivars (Table 6). The high-

Table 3. Results of two-way ANOVA of the effect of cultivars and salt concentrations on the contents of dry matter and water.

\begin{tabular}{|c|c|c|c|c|c|c|c|c|c|c|c|c|c|c|c|c|c|}
\hline \multirow[t]{2}{*}{ Source } & \multirow[b]{2}{*}{ df } & \multicolumn{4}{|c|}{ Dry matter content (g) } & \multicolumn{4}{|c|}{ Dry matter content (\%) } & \multicolumn{4}{|c|}{ Water content (g) } & \multicolumn{4}{|c|}{ Water content (\%) } \\
\hline & & $\begin{array}{c}\text { Sum } \\
\text { of } \\
\text { squares }\end{array}$ & $\begin{array}{l}\text { Mean } \\
\text { square }\end{array}$ & $\mathbf{F}$ & Sig. & $\begin{array}{l}\text { Sum } \\
\text { of } \\
\text { squares }\end{array}$ & $\begin{array}{l}\text { Mean } \\
\text { square }\end{array}$ & F & Sig. & $\begin{array}{l}\text { Sum } \\
\text { of } \\
\text { square }\end{array}$ & $\begin{array}{l}\text { Mean } \\
\text { square }\end{array}$ & $e^{F}$ & Sig. & $\begin{array}{l}\text { Sum } \\
\text { of } \\
\text { square }\end{array}$ & $\begin{array}{l}\text { Mean } \\
\text { square }\end{array}$ & F & Sig. \\
\hline Corrected model & 11 & 5.6 & 0.5 & 22.8 & 0.000 & 93.5 & 8.5 & 5.9 & 0.000 & 296.8 & 27.0 & 52.1 & 0.000 & 93.5 & 8.5 & 5.9 & 0.000 \\
\hline Intercept & 1 & 68.2 & 68.3 & 3040.2 & 0.000 & $16,905.1$ & $16,905.1$ & $11,686.0$ & 0.000 & 2820.3 & 2820.3 & 5449.7 & 0.000 & $168,060.7$ & $168,060.7$ & $116,175.1$ & 10.000 \\
\hline Cultivar & 2 & 0.3 & 0.2 & 6.8 & 0.005 & 8.6 & 4.3 & 3.0 & 0.070 & 25.5 & 12.7 & 24.6 & 0.000 & 8.6 & 4.3 & 3.0 & 0.070 \\
\hline Salt & 3 & 3.7 & 1.2 & 54.5 & 0.000 & 17.8 & 5.9 & 4.1 & 0.017 & 264.4 & 88.1 & 170.3 & 0.000 & 17.8 & 5.9 & 4.1 & 0.017 \\
\hline Cultivar * Salt & 6 & 1.6 & 0.3 & 12.3 & 0.000 & 67.1 & 11.2 & 7.7 & 0.000 & 6.9 & 1.2 & 2.2 & 0.075 & 67.1 & 11.2 & 7.7 & 0.000 \\
\hline Error & 24 & 0.5 & 0.02 & & & 34.7 & 1.4 & & & 12.4 & 0.5 & & & 34.7 & 1.4 & & \\
\hline Total & 36 & 74.4 & & & & $17,033.4$ & & & & 3129.5 & & & & $168,188.9$ & & & \\
\hline Corrected total & 35 & 6.2 & & & & 128.3 & & & & 309.2 & & & & 128.2 & & & \\
\hline
\end{tabular}

Table 4. The effect of different cultivars and salt concentrations on dry matter and water content in sunflower.

\begin{tabular}{|c|c|c|c|c|c|c|c|c|c|c|c|c|c|c|c|c|}
\hline \multirow[t]{2}{*}{ Cultivars } & & \multicolumn{3}{|c|}{ Dry matter content (g) } & \multicolumn{4}{|c|}{ Dry matter content (\%) } & \multicolumn{4}{|c|}{ Water content (g) } & \multicolumn{4}{|c|}{ Water content (\%) } \\
\hline & $\begin{array}{l}\mathrm{NaCl} \\
\text { Cont. } \\
(\mathrm{mM})\end{array}$ & 0 & $50 \quad 150$ & 250 & 0 & 50 & 150 & 250 & 0 & 50 & 150250 & Mean & 0 & 50 & 150 & 250 \\
\hline 'TARSAN 1018' & & $1.98^{\mathrm{a}}$ & $1.36^{\mathrm{bc}} 1.03^{\mathrm{c}}$ & $0.62^{\mathrm{d}}$ & $14.62^{\mathrm{ab}}$ & $12.97^{\mathrm{bcd}}$ & $14.32^{a b c}$ & $13.59^{a b c}$ & 11.58 & 9.16 & 6.193 .86 & $7.69^{\mathrm{b}}$ & $85.38^{\mathrm{d}}$ & $87.03^{\mathrm{abc}}$ & $85.68^{\mathrm{bc}}$ & $86.41^{\mathrm{bcd}}$ \\
\hline 'TR-3080' & & $2.06^{\mathrm{a}}$ & $1.57^{\mathrm{b}} 1.07^{\mathrm{c}}$ & $1.03^{c}$ & $13.00^{\mathrm{bcd}}$ & $13.95^{\mathrm{abc}}$ & $10.89^{\mathrm{cd}}$ & $13.81^{\mathrm{abc}}$ & 13.83 & 9.69 & 8.756 .44 & $9.67^{\mathrm{a}}$ & $87.00^{\mathrm{abc}}$ & $86.05^{b c d}$ & $89.11^{\mathrm{ab}}$ & $86.19^{\mathrm{bcd}}$ \\
\hline '08-TR-003' & & $1.45^{\mathrm{b}}$ & $1.50^{\mathrm{b}} 1.60^{\mathrm{b}}$ & $1.25^{\mathrm{bc}}$ & $9.81^{\mathrm{d}}$ & $14.35^{\mathrm{abc}}$ & $16.08^{\mathrm{ab}}$ & $17.18^{\mathrm{a}}$ & 13.34 & 8.94 & 8.376 .06 & $9.17^{\mathrm{a}}$ & $90.19^{\mathrm{a}}$ & $85.65^{\mathrm{bcd}}$ & $83.92^{\mathrm{cd}}$ & $82.82^{\mathrm{d}}$ \\
\hline & Mean & & & & & & & & $12.91^{\mathrm{a}}$ & $9.26^{\mathrm{b}}$ & $7.77^{\mathrm{c}} 5.45^{\mathrm{d}}$ & & & & & \\
\hline
\end{tabular}




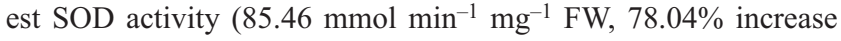
compared to control) was registered in cv. 'TARSAN1018' under high salt stress $(250 \mathrm{mM})$. However, the lowest activity of SOD (80.21 $\mathrm{mmol} \mathrm{min}^{-1} \mathrm{mg}^{-1} \mathrm{FW}$ ) was obtained from 'TR-3080' at the same salt concentration. SOD activities increased by $78.0 \%$, $42.1 \%$ and $43.4 \%$ in 'TARSAN1018', 'TR-3080' and '08-TR003 ', respectively. Many changes have been detected in the activities of antioxidant enzymes in plants under salinity. The activity of antioxidant enzymes was reported to increase under saline conditions in the case of safflower (Siddiqi et al., 2011; Çulha Erdal and Çakirlar, 2014) and sunflower (Rios-Gonzales et al., 2002; Jabeen and Ahmad, 2012). According to our results, SOD seems to be more sensitive in the antioxidative process of salt stressed sunflower plants and more active in cv. "TARSAN1018".

Proline concentration has been often suggested as an indicator of osmotic stress (Khalil et al., 2016). Proline accumulation under salt stress has been correlated with salt tolerance (Mansour and Ali, 2017). In this investigation, the findings showed that salt stress (from $0 \mathrm{mM}$ to $250 \mathrm{mM} \mathrm{NaCl}$ ) considerably enhanced the leaf free proline contents of all sunflower cultivars (Table 6). However, the cultivars differed significantly in proline content. Among the cultivars, 'TR-3080' accumulated considerably more proline $(16.70$

Table 5. Results of two-way ANOVA of the effect of cultivars and salt concentrations on proline content, activities of glutathione reductase (GR), ascorbate peroxidase (APX), lipid peroxidase (MDA) and superoxide dismutase (SOD).

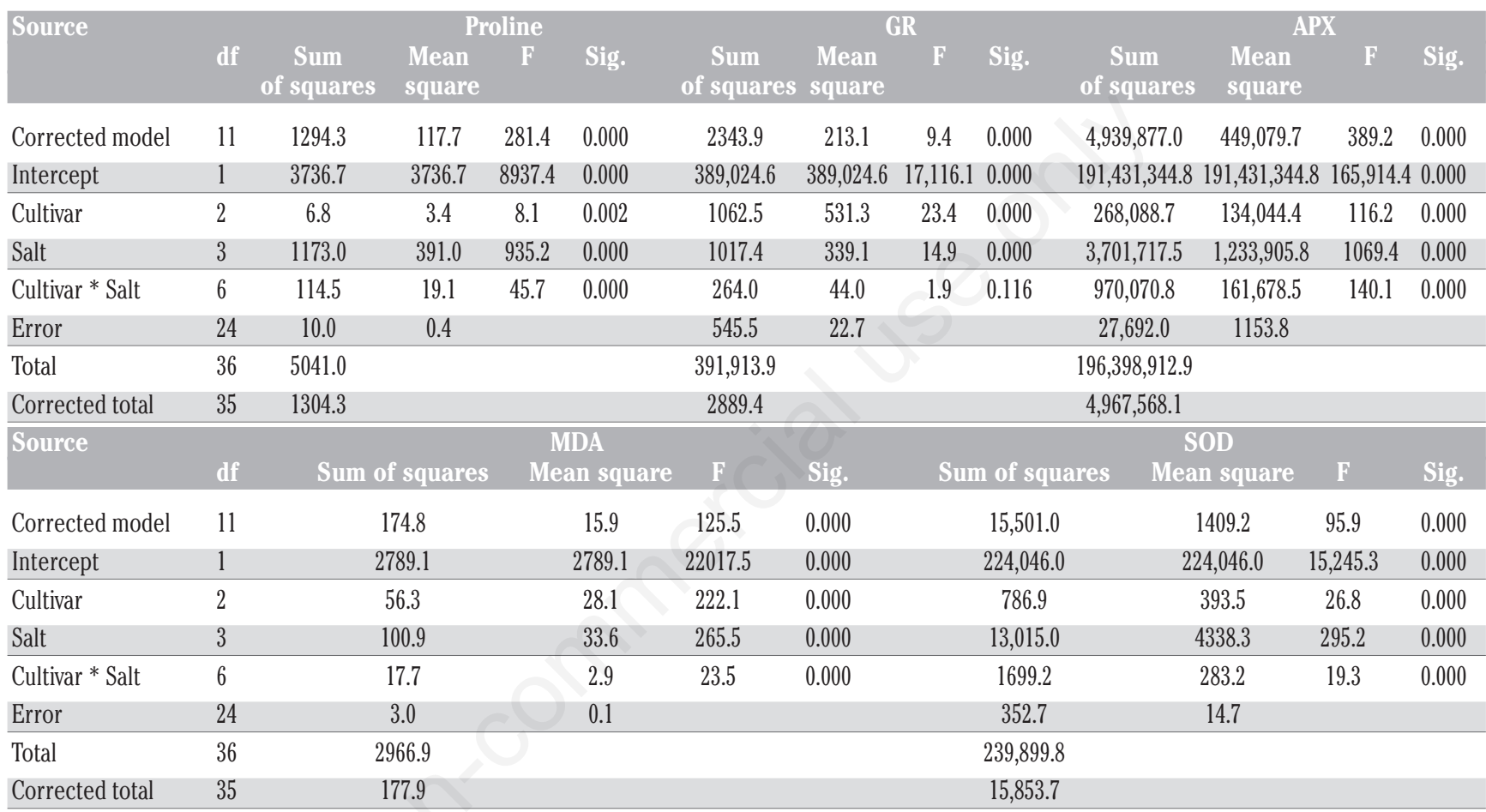

Table 6. The effect of cultivars and salt concentrations on the activity of antioxidant enzymes (GR, APX and SOD) (unit/min./mg fresh weight) and proline content ( $\mu \mathrm{mol} / \mathrm{g}$ fresh weight) with lipid peroxidation (MDA, $\mu \mathrm{mol} / \mathrm{g}$ fresh weight) in sunflower.

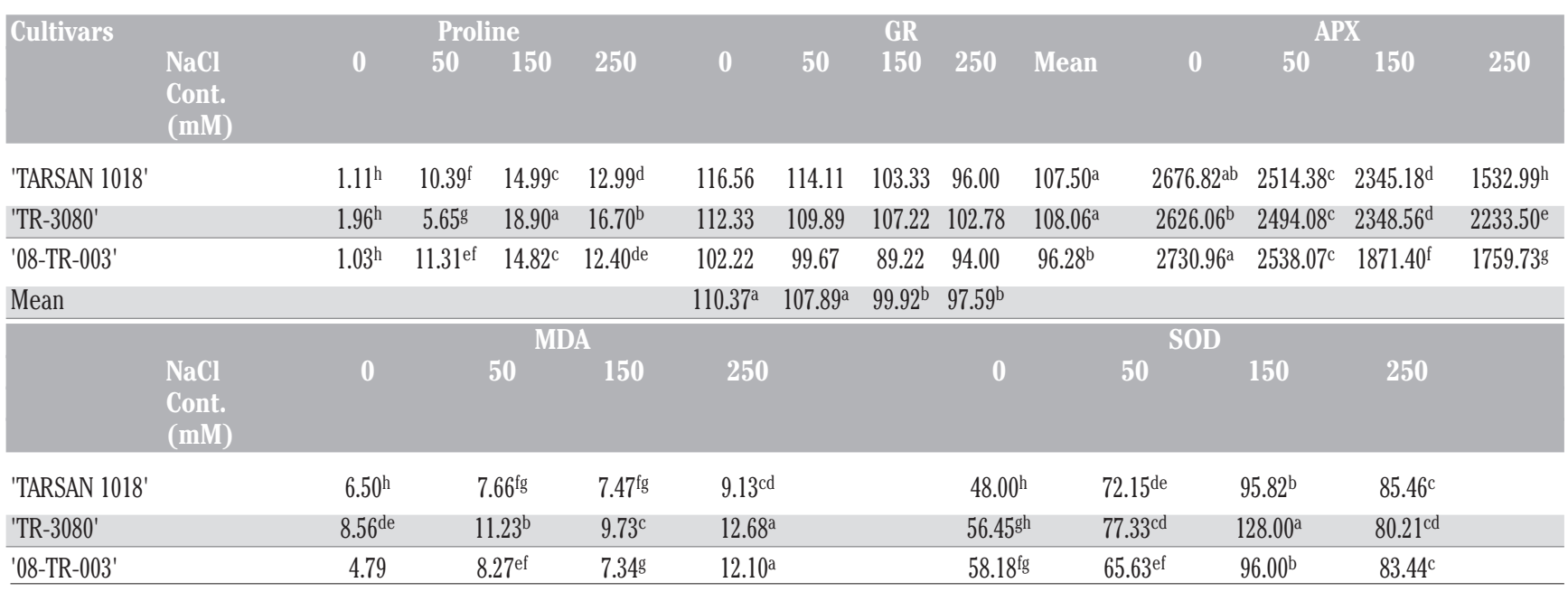

a-hValues in a row and in a column (for glutathione reductase activity) followed by the different letters are significantly different at the 0.01 level. 
$\mu \mathrm{mol} / \mathrm{g} \mathrm{FW}, 752.04 \%$ increase compared to control) than the other sunflower cultivars ('TARSAN1018' with $12.99 \mu \mathrm{mol} / \mathrm{g} \mathrm{FW}$, $1070.27 \%$ increase compared to control and '08-TR-003' with $12.40 \mu \mathrm{mol} / \mathrm{g} \mathrm{FW}, 1103.88 \%$ increase compared to control) under saline conditions. The results of this study are also in agreement with Shahbaz et al. (2011), Jabeen and Ahmad (2012) and Bakhaum and Sadak (2016), who emphasised that salt stress markedly enhanced free proline contents in sunflower cultivars. However, our result showed that there is a negative relationship of morphological traits (plant height, leaf area, fresh weight, dry matter and water contents) with proline accumulation in all sunflower cultivars (Table 6). Khalil et al. (2016), stated that the negative relationship with morphological traits indicated that proline concentration may not be related with enhancing growth in sunflower but could increase survivability under stress contributing to the osmotic adjustment, and could participate in rapid recovery.

Lipid molecules, specifically unsaturated lipids, are sensitive to oxidation by ROS (Rasool et al., 2013). Membrane lipid peroxidation is often used as a marker of an adverse effect of oxidative stress (Ozturk et al., 2012). In the present study, the results of sunflower cultivars showed that with increasing levels of salt stress, MDA content increased (Table 6). The lowest MDA content (9.13 $\mu \mathrm{mol} / \mathrm{g} \mathrm{FW}, 40.46 \%$ increase compared to control) was record in cv. 'TARSAN-1018', while the highest value $(12.68 \mu \mathrm{mol} / \mathrm{g} \mathrm{FW}$, $48.13 \%$ increase compared to control) was registered in cv. 'TR3080 ' at $250 \mathrm{mM} \mathrm{NaCl}$ concentration. For cv. '08-TR-003', MDA content was $12.10 \mu \mathrm{mol} / \mathrm{g} \mathrm{FW}$ with a $152.6 \%$ increase. The findings are in agreement with those obtained by Jabeen and Ahmad (2012) in sunflower. In particular, SOD constitutes the end product of peroxidation of membrane lipids and is the first line of defense against ROS (Hussain et al., 2016). Our result indicated that the lowest MDA content $(9.13 \mu \mathrm{mol} / \mathrm{g} \mathrm{FW})$ and the highest activity (85.46 mmol min $\mathrm{mg}^{-1} \mathrm{FW}$ ) of SOD were obtained from cv. 'TARSAN-1018'. The reason of the lowest MDA content in cv. 'TARSAN-1018' may due to the high activity of SOD.

\section{Conclusions}

The results from this investigation allow to conclude that there are differences in the response to salt stress among sunflower cultivars. In term of morphological (plant height, leaf area, fresh weight, water content) and biochemical [GR, APX and SOD (secondly) activities and proline contents] parameters, cv. 'TR-3080' seems to be less affected from salt stress. Interestingly and unlike other study about the relationship between salt stress and antioxidant enzyme activities, we observed a decreasing activity of the two antioxidant enzymes (GR and APX) under salt stress conditions. On the other hand, similarly with the other studies in the literature, an increased activity was detected for SOD in all cultivars As concerns these findings, cv. 'TR-3080' seems to be less affected by salt stress.

\section{References}

Achakzai AKK, Ur RM, Yaqoob M, Sarangzai AM, Barozai MYK, Din M, 2015. Stem and leaf response of sunflower hybrids to salt stress. Pak. J. Bot. 47:2063-7.

Bajehbaj AA, 2010. The effects of $\mathrm{NaCl}$ priming on salt tolerance in sunflower germination and seedling grown under salinity conditions. Afr. J. Biotechnol. 9:1764-70.

Bakhoum GSH, Sadak MS, 2016. Physiological role of glycine betaine on sunflower (Helianthus annuus L.) plants grown under salinity stress. Int. J. Chem. Tech Res. 9:158-71.

Bates LS, Waldren RP, Teare ID, 1973. Rapid determination of free proline for water stress studies. Plant Soil 39:205-7.

Bela K, Horvatha E, Gallea A, Szabadosb L, Tari I, Csiszara J, 2015. Plant glutathione peroxidases: Emerging role of the antioxidant enzymes in plant development and stress responses. J. Plant Physiol. 176:192-201.

Cakmak I, Atlı M, Kaya R, Evliya H, Marschner H, 1994. Association of high light and zinc deficiency in cold-induced leaf chlorosis in grapefruit and mandarin trees. J. Plant Physiol. 146:355-60.

Cakmak I, Marschner H, 1992. Magnesium deficiency and highlight intensity enhance activities of superoxide dismutase, ascorbate peroxidase and glutathione reductase in bean leaves. Plant Physiol. 98:1222-6.

Ceccoli G, Senn ME, Bustos D, Ortega LI, Córdoba A, Vegetti A, Taleisnik E, 2012. Genetic variability for responses to shortand long-term salt stress in vegetative sunflower plants. J. Plant Nutr. Soil Sci. 175:882-90

Çulha Erdal Ş, Çakirlar H, 2014. Impact of salt stress on photosystem II efficiency and antioxidant enzyme activities of safflower (Carthamus tinctorius L.) cultivars. Turk J Biol. 38:549-60.

Dale JE, 1988. The control of leaf expansion. Annu. Rev. Plant Physiol. 39:267-95.

Gill SS, Tuteja N, 2010. Reactive oxygen species and antioxidant machinery in abiotic stress tolerance in crop plants. Plant Physiol. Biochem. 48:909-30.

Hsia TC, 1973. Plant responses to water stress. Annu. Rev. Plant Physiol. 24:219-70.

Hussain M, Farooq M, Shehzad M, Khan MB, Wahid A, Shabir G, 2012. Evaluating the Performance of Elite Sunflower Hybrids under Saline Conditions. Int. J. Agric. Biol. 14:131-5.

Hussain MI, Lyra DA, Farooq M, Nikoloudakis N, Khalid N, 2016. Salt and drought stresses in safflower: a review. Agron. Sustain. Dev. 36:4.

Jabeen N, Ahmad R, 2012. Improvement in growth and leaf water relation parameters of sunflower and safflower plants with foliar application of nutrient solutions under salt stress. Pak. J. Bot. 44:341-5.

Karmoker JL, Van Steveninck FM, 1979. The effect of abscisic acid on the uptake and distribution of ions in intact seedlings of Phaseolus vulgaris cv. Redland Pioneer. Physiol. Plant. 45:453-9.

Khalil F, Rauf S, Monneveux P, Anwar S, Iqbal Z, 2016. Genetic analysis of proline concentration under osmotic stress in sunflower (Helianthus annuus L.). Breed. Sci. 66:463-70.

Khan WM, Khan MS, Karim S, Umar N, Sajjad A, 2016. Effect of salt stress on some morphological and biochemical characteristics of sunflower (Samsung-600). Pure Appl. Biol. 5:653-63.

Koç A, 2015. Effect of plant growth-promoting bacteria and arbuscular mycorrhizal fungi on lipid peroxidation and total phenolics of strawberry (Fragaria $\times$ ananassa 'San Andreas') under salt stress. Turk. J. Agric For. 39:992-8.

Kumar S, Ahmad A, Rao V, Masood A, 2014. Effect of salinity on growth and leaf area of sunflower (Helianthus annuus L.) cv. Suntech-85. Afr. J. Agric. Res. 9:1144-50.

Lutts S, Kinet JM, Bouharmont Kinet, Bouharmont J, 1996. NaClInduced senescence in leaves of rice (Oryza sativa 1.) cultivars differing in salinity resistance. Ann. Bot. 78:389-98.

Ma T, Zeng W, Li Q, Wu J, Huang J, 2016. Effects of water, salt 
and nitrogen stress on sunflower (Helianthus annuus L.) at different growth stages. J. Soil Sci. Plant Nutr. 16:1024-37.

Machekposhti MF, Shahnazaria A, Ahmadia M., Aghajania G, Ritzemab H, 2017. Effect of irrigation with sea water on soil salinity and yield of oleic Sunflower. Agricult. Water Manage. 188:69-78.

Maia FMA, Costa AC, de Castro JN, Megguer CA, Soares FAL, 2016. Photosynthesis and water relations of sunflower cultivars under salinity conditions. Afr. J. Agric. Res. 11:2817-24.

Mansour MMF, Ali EF, 2017. Evaluation of proline functions in saline conditions. Phytochemistry 140:52-68.

Masor LL, 2011. Determining salt tolerance among sunflower genotypes. (Msc. Thesis). Texas A\&M University.

Nobre RG, Gheyi HR, Correia KG, Soares FAL, Andrade LO, 2010. Crescimento e floração do girassol sob estresse salino e adubação nitrogenada. Rev. Ciênc. Agron. 41:358-65.

Nxele X, Klein A, Ndimba BK, 2017. Drought and salinity stress alters ROS accumulation, water retention, and osmolyte content in sorghum plants. S. Afr. J. Bot. 108:261-6.

Ozturk L, Demir Y, Unlukara A, Karatas I, Kurunc A, Duzdemir O, 2012. Effects of long-term salt stress on antioxidant system, chlorophyll and proline contents in pea leaves. Roman. Biotechnol. Lett. 17:7227-36.

Per TS, Khan NA, Reddy PS, Masood A, Hasanuzzaman M, Iqbal M, Khan R, Anjum NA, 2017. Approaches in modulating proline metabolism in plants for salt and drought stress tolerance: Phytohormones, mineral nutrients and transgenics. Plant Physiol. Biochem. 115:126-40.

Prado FE, Gonzalez JA, Gallardo M, Moris M, Boero C, Kortsarz A, 1995 Changes in soluble carbohydrates and invertase activity in Chenopodium quinoa ("quinoa") developed for saline stress during germination. Curr. Top. Phytochem. 14:1-5.

Rasool S, Ahmad A, Siddiqi TO, Ahmad P, 2013. Changes in growth, lipid peroxidation and some key antioxidant enzymes in chickpea genotypes under salt stress. Acta Physiol. Plant. $35: 1039-50$
Rios-Gonzalez K, Erdei L, Lips SH, 2002. The activity of antioxidant enzymes in maize and sunflower seedlings as affected by salinity and different nitrogen sources. Plant Sci. 162:923-30.

Rivelli AR, De Maria S, Pizza S, Gherbin P, 2010. Growth and physiological response of hydroponically-grown sunflower as affected by salinity and magnesium levels. J. Plant Nutr. 33:1307-23.

Shahbaz M, Ashraf M, Akram NA, Hanif A, Hameed S, Joham S, Rehman R, 2011. Salt-induced modulation in growth, photosynthetic capacity, proline content and ion accumulation in sunflower (Helianthus annuus L.). Acta Physiol. Plant. 33:1113-22.

Siddiqi EH, Ashraf M, Al-Qurainy F, Akram NA, 2011. Saltinduced modulation in inorganic nutrients, antioxidant enzymes, proline content and seed oil composition in safflower (Carthamus tinctorius L.). J Sci. Food Agric. 91:2785-93.

Snedecor GW, Cochran WG, 1967. Statistical Methods. The Iowa State University Press, Iowa, USA.

Steduto P, Albrisio R, Giorio P, Sorrentino G, 2000. Gas-exchange response and stomatal and non-stomatal limitations to carbon assimilation of sunflower under salinity. Environ. Exp. Bot. 44:243-55.

Sunderland N, 1960. Cell division and expansion in the growth of the leaf. J. Exp. Bot. 11:68-80.

Van Volkenburg E, Boyer JS, 1985. Inhibitory effects of water deficit on maize leaf elongation. Plant Physiol. 77:190-4.

Vighi IL, Benitez LC, Amaral MN, Moraes GP, Auler PA, Rodrigues GS, Deuner S, Maia LC, Braga EJB, 2017. Functional characterisation of the antioxidant enzymes in rice plants exposed to salinity stress. Biol. Plant. 61:540-50.

Wen-Zhi Z, Chi X, Jing-Wei W, Jie-Sheng H, Qiang Z, Mou-Song $\mathrm{W}, 2014$. Impacts of salinity and nitrogen on the photosynthetic rate and growth of sunflowers (Helianthus annuus L.). Pedosphere 24:635-44.

You J, Chan Z, 2015. ROS regulation during abiotic stress responses in crop plants. Front. Plant Sci. 6:1-15. 